\title{
STRUKTURALIZACE A ANALÝZA FAKTORŮ OVLIVŇUJÍCÍCH EFEKTIVNOST FÚZÍ A AKVIZIC
}

\author{
Stanislav Konkolski
}

\section{Klíčová slova:}

Akvizice, fúze, motivace pro akvizice, integrační proces, klíčové faktory úspěchu F\&A, zisk, ekonomická přidaná hodnota (EVA), tvorba hodnoty pro akcionáře (VBM), investovaný kapitál, vážené průměrné náklady kapitálu (WACC), zisk z operativní činnosti podniku po zdanění (NOPAT)

\section{Keywords:}

Acquisition, merger, motivation for the acquisition, integration process, the key success factors in M\&A, profit, Economic Value Added (EVA), value based management (VBM), capital, weighted average cost of capital (WACC), Net Operating Profit After Taxes (NOPAT)

\begin{abstract}
Abstrakt:
Odborný obsah tohoto článku vychází z mé disertační práce, ${ }^{1}$ zpracované na téma procesu řízení slučování podnikatelských subjektů na bázi fúzí či akvizic se zaměřením na strukturalizaci a analýzu stěžejních faktorů, ovlivňujících úspěšnost řízení procesů sloučení. Nejedná se o výběr a analýzu vysoce relevantních metod a postupů hodnocení výsledků slučovacího procesu. Pro hodnocení úspěšnosti a efektivnosti fúzí či akvizic (F\&A), nebo také pro hodnocení výkonnosti F\&A (post acquisition performance) je použita metoda EVA (Economic Value Added), dále jsou použity ukazatele EVA/tržby, EVA/aktiva, EVA/ vlastní kapitál. Pro zjišsění vlivu některých faktorů na úspěšnost, výkonnost podniků v postakvizičním období, jsou dále použity ukazatele EBITDA/aktiva a EBITDA/tržby. Měřené období změny výkonnosti zkoumaného souboru podniků jsou 3 roky před provedenou akviziční transakcí a 3 roky po provedené akviziční transakci.

Statistická ověřování při použití Wilcoxonova testu potvrdilo šest faktorů s velkým vlivem na výkon podniku po provedené akvizici. Vyvozené závěry, zjištěné výzkumnými šetřeními, které byly provedené v rámci zpracované disertační práce, vedou k stanovení návrhu souboru opatření a postupů řízení projektu $F \& A$, které zvyšují pravděpodobnost úspěšnosti a efektivnosti realizace těchto projektů. Tento soubor návrhu opatření je velmi těsně spjat se zjištěnými klíčovými faktory úspěšnosti F\&A a to hlavně s plánem integračního procesu, jmenováním managementu, lidským činitelem a due diligenci.
\end{abstract}

\begin{abstract}
:
The expert content of the article is based on my thesis elaborated on theme of processes related to management of combining business entities, on the basis of mergers or acquisitions, concentrated on structuring and an analysis of cardinal factors affecting successfulness of M\&A (mergers and acquisitions) processes management. Selection and an analysis of highly relevant methods and procedures for evaluation of M\&A processes results are not dealt with here. The method EVA (economic value added) is used for assessment of successfulness and effectiveness of M\&A or for evaluation of M\&A performance efficiency (post acquisition
\end{abstract}

\footnotetext{
${ }^{1}$ KONKOLSKI, S., Strukturalizace a analýza faktorů ovlivňujicich efektivnost fúzí a akvizic. 2011. $192 \mathrm{~s}$ bez ISBN
} 
performance). Other used indicators are EVA/revenues, EVA/assets, EVA/equity capital. Besides, EBITDA/assets and EBITDA/revenues are used to find out some factors influence on successfulness and efficiency of the companies in post acquisition period. The measured period of a performance change in the examined set of companies starts 3 years before and ends 3 years after an accomplished acquisition transaction.

Statistical verifying using Wilcoxon's test confirmed six factors with a huge impact on a company performance after an accomplished acquisition. Drawn conclusions obtained within the research examinations of the thesis lead to a proposed package of measures and procedures to manage a M\&A project. They increase probability of successfulness and efficiency of implementation of these projects. This set of measures is closely connected with uncovered key factors of M\&A successfulness, mainly with a plan of integration process, appointment of the management, a human factor and due diligence.

\section{Úvod}

Fúze a akvizice podniků (společností) jsou jedním z nejvýznamnějších jevů posledních dvou dekád ekonomického života v České republice a ve světě vůbec. Fúze a akvizice zasáhly mnoho společností napříc podnikatelským spektrem, jak ve vysoce rozvinutých zemích, tak i v zemích rozvíjejících se. Je nutné je vnímat jako jednu z hlavních forem integrace, která umožňuje společnostem vytvářet konkurenční převahu. Fúze a akvizice jsou spojeny s velmi komplikovanými rozhodnutími jak finančními, tak investičními. Zahrnují všechny klíčové prvky podnikání, strategického řízení a analýzy, bankovnictví, regulace kapitálových trhů, pracovního práva, financí, daní, účetnictví, řízení lidských zdrojủ, řízení hodnoty podniku a navazuji na procesy restrukturalizace a integrace. Bezchybné provedení fúze či akvizice vyžaduje proto rozsáhlé znalosti a kompetence, dokonalou týmovou práci odborníků s vysokou úrovní znalostí a praktickými zkušenostmi v uvedených oborech.

Ve zpracovaných studiích a publikované literatuře, které se oblasti fúzí a akvizic v České republice zabývají, není oblast ř́zení projektů fúzí a akvizic řešena komplexně. Autoři se většinou zaměřují na vybrané oblasti akvizic, zejména na účetní, daňové nebo právní aspekty fúzí a akvizic. Touto oblastí se zabývá celá řada autorů, jako př́klad lze uvést publikace a studie Vomáčkové Hany, Účetnictví akvizicí, fúzí a jiných vlastnických transakcí (2006) ${ }^{2}$; Louša F. Účetnictví podnikatelů (2006) ${ }^{3}$. V oblasti managementu lze nalézt taktéž celou řadu publikací a informačních zdrojů, ale i zde je problematice projektů fúzí a akvizic věnovaná pozornost spíše doplňková, Synek M. a kolektiv $(2007){ }^{4}$, Veber J. a kolektiv (2006). ${ }^{5}$

Tyto důvody vedly autora k provedení výzkumu a zjištění faktorů ovlivňujících projekty F\&A. Tento výzkum se stal součástí disertační práce s názvem „Strukturalizace a analýza faktorů ovlivňujících efektivnost fúzí a akvizic“ z roku 2011. Disertační práce je cílově zaměřená v návaznosti na předešlé výzkumy dostupných informačních zdrojů k realizovaným projektům fúzí a akvizic na zjišsění faktorů podstatně ovlivňujících efektivnost, nebo výkonnost

\footnotetext{
${ }^{2}$ VOMÁČKOVÁ, H.,Účetnictví akvizici, füzi a jiných vlastnických transakcí. Praha : Polygon, 2006, s. 560. ISBN 80-7273$127-0$.

${ }^{3}$ LOUŠA, F., Účetnictví podnikatelů 2006 : výklad je zpracován k právnímu stavu ke dni 1.1.2006. Praha : ASPI, 2006. s.758. ISBN 80-735-7155-2.

${ }^{4}$ SYNEK, M., kol., Manažerská ekonomika.. 4. aktualiz. vyd.: Praha : Grada, 2007. , s. 464. ISBN 80-247-1992-4. s. 343.

${ }^{5}$ VEBER, J., kol., Management: základy, prosperita, globalizace. Praha : Management Press, 2004, s. 700. ISBN 80-7261029-5.
} 
podniků, které se na akvizičních procesech podílejí. Obsahovým těžištěm řešení problematiky této disertační práce, a tím i zpracovaného článku, který vychází z této disertační práce je problematika procesu řízení slučování podnikatelských subjektů, na bázi fúzí a akvizic, se zaměřením na strukturalizaci a analýzu stěžejních faktorů, ovlivňujících úspěšnost řízení procesu sloučení. Nejedná se o výběr a analýzu vysoce relevantních metod a postupů hodnocení finančních výsledků slučovacího procesu.

Zkoumání předmětné problematiky je také zaměřeno na identifikaci možných rizik a př́ležitostí souvisejících s řízením projektů fúzí a akvizic. Záměrem je předložit ucelený pohled na projekty fúzí a akvizic od identifikace základních motivů k provedení akvizic, přes identifikaci vhodných cílových společností, prověření předmětu fúze či akvizice až po vhodné stanovení způsobu začlenění a integrace do „nové“ organizační struktury kupujícího.

\section{1. Řešení předmětné problematiky}

Cílem hodnocení úspěšnosti a efektivnosti F\&A není stanovení nejsofistikovanější metody kritérií pro samotné hodnocení výsledků F\&A, ale cílem je potvrdit existenci a působení rozhodujících faktorů a procesů ovlivňujících úspěšnost projektů $\mathrm{F} \& A$. Cílem disertační práce je především potvrdit, že $\mathrm{v}$ případě ignorování rozhodujících faktorů a procesů ovlivňujících úspěšnost a efektivnost projektů F\&A, jsou fúze neúspěšné.

(C1): Primárním cílem řešení problematiky disertační práce je zjištění rozhodujících faktorů a procesů ovlivňujících úspěšnost a efektivnost zpracování a řízení projektů akvizic a fúzí. Účelem stanovení těchto faktorů je návrh takových postupů ř́zení projektů fúzí a akvizic, které budou maximalizovat pravděpodobnost úspěšnosti a efektivnosti těchto projektů fúzí a akvizic.

Pro hodnocení úspěšnosti a efektivnosti F\&A (post acquisition performance) jsem použil metodu EVA (Economic Value Added). Z důvodu odstranění vlivu ve velikosti podniku je dále ukazatel EVA vyjádřen v relativní formě a to: EVA/tržby, EVA /aktiva, EVA / vlastní kapitál. Pro zjištění vlivů některých faktorů na úspěšnost výkonnost podniků v postakvizičním období, jsem dále ještě použil ukazatelů EBITDA/aktiva a EBITDA/tržby.

Důvody použití tohoto způsobu měření úspěšnosti a efektivnosti (výkonnosti) jsou blíže uvedeny v disertační práci „Strukturalizace a analýza faktorů ovlivňujících efektivnost fúzí a akvizic" 6 . Dále rozhodnutí o aplikaci metody EVA bylo spojeno s poznatky získanými např. z akademických prací a výzkumů, profesora Ken C. Yook „The measurement of postacquisition performance using EVA“ zveřejněném v Quarterly Journal of Business end Economics, University of Nebraska-Lincoln (2004). ${ }^{7}$

Měření výkonnosti podniků v postakvizičním období pomoci ukazatelů provozní výkonnosti EBITDA (Earning Before Interest, Taxes, Depreciation and Amortization) je použito např́í-

\footnotetext{
${ }^{6}$ KONKOLSKI, S., Strukturalizace a analýza faktorů ovlivňujicich efektivnost fúzí a akvizic. 2011. $192 \mathrm{~s}$ bez ISBN

${ }^{7}$ YOOK, K. C., The measurement of post-acquisition performance using EVA. Quarterly Journal of Business nad Economics, University of Nebraska-Lincoln, June 22.,2004,svazek 43, vyyd. 3-4 : s. 67., Dostupný také

z w.w.w:<file:///C:/Documents\%20and\%20Settings/J002748/Local\%20Settings/Temporary\%20Internet\%20Files/OLK5D4/ The $\% 20$ measurement $\% 20$ of $\% 20$ post-

acquisition\%20performance\%20using\%20EVA\%20(economic\%20value\%20added).htm>.
} 
klad ve výzkumné práci „The long-term operating performance of European mergers and acquisitions“, Martynova M., Oosting, S., Renneboog (2006). ${ }^{8}$

Měřené období jsou 3 roky před a 3 roky po provedené akvizici. Tento časový interval je stanoven na základě doporučení prof. Synka M., Manažerská ekonomika (2007). ${ }^{9}$ Časový interval 3 let před i po akvizici byl rovněž použit ve výzkumech provedených v uplynulých létech jako např́klad: „The postmerger financial performance of hotel companies“ Li-Tzang (Jane) Hsu, SooCheong (Shawn) Jang (2007) ${ }^{10}$, nebo ,The long-term operating performance of European mergers and acquisitions“" Martynova, Oosting. Renneboog (2006) ${ }^{11}$.

Úspěšnost a efektivnost fúze a akvizice je vnímána $v$ disertační práci i v tomto článku jako tvorba hodnoty podniku a je měřená pomoci ukazatele EVA.

Na primární cíl řešení problematiky disertační práce je napojen analytický cíl C2:

C2): Analyzovat dopady organizačních, sociálních a kulturních změn, které jsou vyvolány změnami doprovázejícími slučovacími procesy při realizaci projektu $\mathrm{F} \& A$ s cílem stanovit postupy, zvyšující pravděpodobnost úspěšnosti integračního procesu $\mathrm{s}$ vazbou na konkrétně realizované slučovací procesy, šetřené $v$ rámci primárního výzkumu.

Sběr dat, které byly potřebné k správnému provedení výzkumných šetření, jenž jsou součástí mé disertační práce je možné rozdělit do dvou částí:

První část je spojená se sekundárním výzkumem, což znamenalo studium materiálů dostupných $\mathrm{k}$ dané problematice $\mathrm{v}$ České republice i zahraničí. Po prostudování a zmapování situace v České republice byla pozornost zaměřena na zahraniční literaturu, kde můžeme konstatovat daleko větší rozsah zdrojů informací. Seznam literatury je uveden v závěru tohoto článku.

Druhá část se týkala provedení primárního výzkumu. Primární výzkum dotazníkovým šetřením byl proveden v určité skupině společností sídlících na území České republiky s cílem získat údaje a data o průběhu př́pravy a realizace projektů fúzí či akvizic v oblasti personálně sociální. Dále byla využita metoda rozhovoru v rámci primárního výzkumu mezi špičkovými vedoucími pracovníky společností, jež se fúze či akvizice zúčastnily. Cílem tohoto výzkumu bylo získat informace o pořadí důležitosti a významu jednotlivých faktorů-procesů ovlivňujících průběh a výsledek fúzí či akvizic. V rámci této druhé části byla rovněž soustředěna potřebná data $\mathrm{z}$ výročních zpráv jednotlivých společností ve zkoumaném časovém období. Zdrojem dat dále byly:

- Rozvahy společností

- Výkazy zisku a ztrát

- Př́lohy k účetním ročním závěrkám

- Přehledy o peněžních tocích

- Z Z Zrávy o vztazích mezi ovládající a ovládanou osobou a o vztazích mezi ovládanou osobou a ostatními osobami ovládanými stejnou ovládající osobou

\footnotetext{
${ }^{8}$ MARTYNOVA, M.,OOSTING, S., RENNEBOOG, L., The long-term operating performance of European mergers and acquisitions, Finance working paper $\mathrm{N}^{\circ} .137 / 2006$, November. 2006, Dostupné na www:<

http://www.marketobservation.ch/blogs/media/blogs/c_f/20072602-EuropMA.pdf $>$.

${ }^{9}$ SYNEK, M., kol., Manažerská ekonomika.. 4. aktualiz. vyd.: Praha : Grada, 2007., s. 464. ISBN 80-247-1992-4. s. 343.

${ }^{10}$ HSU, L., JANG, S., The Postmerger Financial Performance of Hotel Companies, Dostupné na www:<http://ebookbrowse.com/hsu-yang-2007-the-postmerger-financial-performance-of-hotel-companies-pdf-d61005413>. ${ }^{11}$ MARTYNOVA, M.,OOSTING, S., RENNEBOOG, L., The long-term operating performance of European mergers and acquisitions, Finance working paper $N^{\circ} .137 / 2006$, November. 2006, Dostupné na www:<

http://www.marketobservation.ch/blogs/media/blogs/c_f/20072602-EuropMA.pdf>.
} 
- Smlouvy

- Notářské zápisy

- Zprávy auditorů

\section{Zpracování dat a použité metody}

Ke zpracování dat jsou použity statistické metody, a to takto:

1. Pro ověření stupně důležitosti (klíčovosti) jednotlivých faktorů týkajících se obav ze změn vyvolaných fúzí či akvizicí pro jednotlivé zaměstnanecké skupiny (specialisté, mistři, vedoucí a na straně druhé dělníci) jsou použity neparametrické Mann - Whitney U Testy. Ke statistickému zpracování je rovněž použit statistický software SPSS verze 15 a program Microsoft Office Excel 2007.

2. Hodnocení faktorů úspěšnosti slučovacího procesu je ověřeno na základě vypočítaných absolutních a relativních četností a využitím konstrukce $95 \%$ intervalu spolehlivosti $(95 \%$ CI) pro rozdělení pravděpodobnosti. Intervaly spolehlivosti byly spočítány jako meze spolehlivosti pro parametr alternativního rozdělení) Likeš, J. - Laga, J., (1978).

Testy normality Shapiro - Wilk jsou použity při testování hodnot EVA (Economic Value Added) Ekonomická přidaná hodnota před a po F\&A, stejně tak Wilcoxonův párový test. Interval spolehlivosti je spočítán jako meze spolehlivosti pro parametr alternativního rozdělení. ${ }^{13}$

3. Analýza ekonomických výsledků získaných prostřednictvím rozvah jednotlivých společností, výkazů zisků a ztrát, přehledů cash-flow atd., je provedena pomocí souboru softwarové aplikace MS Excel nazvaný SATE (soubor pro analýzu tvorby EVA).

Tato analýza ekonomických výsledků nám umožní porovnat vypočtené hodnoty ukazatele EVA za období tři let před zahájením integračního procesu s obdobím dvou let po integračním procesu. Růst či pokles hodnoty ukazatele EVA nám umožní usuzovat o úspěchu či neúspěchu provedené transakce. Stejně tak bude možné porovnat ukazatele EVA / vlastní kapitál za období tří let před a po zahájení slučovacího procesu s cílem určit, zda proces byl úspěšný (hodnota ukazatele roste) či nikoliv (hodnota ukazatele klesá).

\section{Výsledky sekundárního výzkumu}

Závěrem zkoumání dostupných materiálů je shrnutí výsledků analýzy současného stavu problematiky zabývající se klíčovými faktory, které ovlivňují výsledek fúze a akvizice. Toto shrnutí je obsahem tabulky č.1.

\footnotetext{
${ }^{12}$ LIKEŠ, J., LAGA, J., Základní statistické tabulky. Praha : SNTL, 1978. s. 488. bez ISBN.

${ }^{13}$ LIKEŠ, J,. LAGA, J., Základni statistické tabulky. Praha : SNTL, 1978. s. 488. bez ISBN. s. 51.
} 
Tabulka 1 Shrnutí výsledků analýzy klíčových faktorů ovlivňujících akvizici dle jednotlivých autorů

\begin{tabular}{|c|c|c|}
\hline Prof. CZESLAW ZAJĄC & $\begin{array}{l}\vec{\nu} \\
\dot{\nu} \\
\dot{\nu}\end{array}$ & $\begin{array}{l}\text { Plán integrace a př́íprava HRM během integrace } \\
\text { Kulturní rozdíly } \\
\text { Komunikace } \\
\text { Motivační systém }\end{array}$ \\
\hline $\begin{array}{l}\text { KPMG, PWC, MC KINSEY, BOOZ ALLEN HA- } \\
\text { MILTON, PAUL A. PAUTLER }\end{array}$ & 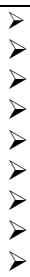 & $\begin{array}{l}\text { Plán integrace } \\
\text { Rychlost integrace } \\
\text { Lídr týmu } \\
\text { Motivační systém } \\
\text { Kulturní rozdíly a komunikace } \\
\text { Udržení špičkových odborníků } \\
\text { Zaměření se na zákazníka } \\
\text { Vhodný výběr společnosti } \\
\text { Managemet s hlubokou znalostí problematiky F\&A }\end{array}$ \\
\hline KELLY, COOK, SPITZER & $\frac{1}{D}$ & $\begin{array}{l}\text { Předběžná ocenění očekávané synergie } \\
\text { Plán integrace } \\
\text { Due diligence } \\
\text { Výběr manažerského týmu } \\
\text { Zohlednění kulturních odlišností } \\
\text { Komunikace }\end{array}$ \\
\hline PETER DRUCKER & 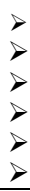 & $\begin{array}{l}\text { Akvizice musí vycházet ze strategie podniku } \\
\text { Jaký bude přínos ze strany akvizitora? } \\
\text { Pouze finanční propojení nestačí } \\
\text { Respekt k hodnotám a kultuře cílové společnosti } \\
\text { Silný management } \\
\text { Vytvoření nových příležitostí pro zaměstnance }\end{array}$ \\
\hline A.T. KEARNEY & 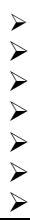 & $\begin{array}{l}\text { Problém formálního sloučení } \\
\text { Silný management } \\
\text { Slučovací proces je zdrojem růstu } \\
\text { Citlivý pŕístup ke snižování zaměstnanosti } \\
\text { Kulturní rozdíly } \\
\text { Komunikace } \\
\text { Risk management }\end{array}$ \\
\hline GE & 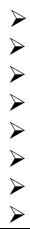 & $\begin{array}{l}\text { Nepodlehnout vlivu integrovaného kandidáta } \\
\text { Špatně provedený Due Diligence } \\
\text { Nereálná očekávání } \\
\text { Neschopnost rychlé integrace } \\
\text { Chybějící společná vize } \\
\text { Konflikty podnikových nebo národních kultur } \\
\text { Nedostatečné zajišténí zdrojů k dokončení integrace } \\
\text { Nezavedení systému odměňování a kriterí měřitelnosti }\end{array}$ \\
\hline ECGI & $>$ & Velikost cílové společnosti čili velikost převzetí \\
\hline
\end{tabular}

Zdroj: vlastní konstrukce

Po porovnání závěrů materiálů, dle jednotlivých autorů, je konstatováno, že tito se shodují v následujících faktorech ovlivňujících $\mathrm{F} \& \mathrm{~A}$ :

1. Plán integračního procesu

2. Rychlost integračního procesu (dodržení předem stanoveného časového har -monogramu integrace)

3. Due diligence

4. Výběr manažerského týmu a lídra týmu

5. Zohlednění kulturních rozdílů ve slučovaných společnostech

6. Komunikace 


\section{Vlastní primární výzkum a strukturalizace klíčových faktorů ovlivňujících vý- konnost podniků podílejících se na akvizičním procesu}

Tato část disertační práce je věnována vlastním výsledkům výzkumné práce. Mimo kritickou literární rešerši se výzkum zaměřil na stávající praxi prováděných akvizičních procesů ve společnostech na území České republiky.

První část šetření byla realizována prostřednictvím důvěrných hovorů s top manažery 39 společností, které se podílely na celkem 19 akvizicích na území České republiky. Celkový počet rozhovorů s představiteli top managementů činil 25. Dotazovaní byli v době realizace akvizice členy vedení ovládajících a rovněž cílových společností. Šetření bylo provedeno v období 2000 - 2009, pro toto šetření byl použit předem připravený seznam otázek, uvedených v dotazníku:

1. Způsob provedení F\&A a vliv faktorů úspěšnosti na výsledek F\&A

Druhá část šetření byla realizována dotazníkovou formou v období let 1999 - 2009. Byly vypracovány následující dotazníky:

1. Motivace pro akvizice

2. Vyhodnocení průběhu přípravy a provedení integračního procesu z personálně-sociálního pohledu

3. Obavy a očekávání vyplývající ze změn vyvolaných F\&A

4. Klíčové faktory úspěšnosti F\&A

Výběr společností byl proveden dle následujících kritérií:

- Společnost se musela účastnit akvizičního procesu

- Dostupnost ekonomických a finančních údajů

- Možnost komunikace s vedoucími pracovníky jednotlivých společností, rovněž i možnost provedení dotazníkového průzkumu mezi zaměstnanci.

Analýza úspěšnosti F\&A byla provedena v celkovém počtu 39 podniků, z kterých $69 \%$ byly akciové společnosti (27) a $31 \%$, tj. 12 podniků, byly společnosti s ručením omezením. $\mathrm{Z}$ tohoto počtu tř̌i akciové společnosti se podílely na víc než jedné akvizici. Mezi základní charakteristiky 39 zkoumaných podniků byly zařazeny: oblast podnikání, počet zaměstnanců a velikost obratu. Z pohledu hlavního druhu činnosti je možné vzorek rozdělit do 5 skupin, přičemž více jak polovinu (79\%) tvoří podniky hutní prvovýroby a druhovýroby a strojírenství. Další část je tvořena podniky zabývajícími se stavební činností (5\%), zpracováním kovového odpadu a šrotu ( $8 \%)$, obchodní činností $(5 \%)$ a spalováním odpadů (3\%).

Pokud se jedná o zaměstnance, je naprosto dominantní skupina velkých podniků s počtem zaměstnanců nad $250(72 \%)$ a skupina podniků s počtem zaměstnanců od $50-250(22$ \%). Naprosto marginální jsou skupiny podniků s počtem zaměstnanců do 50 pracovníků (3\%) a do 10 pracovníků (3\%).

Podle velikosti ročního obratu je skupina podniků rozdělena následovně: 
Tabulka 2 Rozdělení skupiny podniků podle velikosti ročního obratu

\begin{tabular}{|l|c|c|}
\hline & & Počet podniků \\
\hline Roční obrat do 100 mil. CZK & $8 \%$ & 3 \\
\hline Roční obrat 100 - 500 mil. CZK & $23 \%$ & 9 \\
\hline Roční obrat 500 - 1000 mil. CZK: & $15 \%$ & 6 \\
\hline Roční obrat nad 1 000 mil. CZK & $54 \%$ & 21 \\
\hline Počet podniků celkem & & 39 \\
\hline
\end{tabular}

Zdroj: vlastní konstrukce

Dotazníky byly do jednotlivých podniků předány osobně vedoucím pracovníkům $\mathrm{k}$ distribuci. V části podniků byly dotazníky prredány osobně jednotlivým pracovníkům spolu s vysvětlením podávajícím informace o cílech a záměrech výzkumu. Osobním jednáním bylo dosaženo nadprůměrné návratnosti dotazníků. Celková návratnost všech dotazníků byla 507 z celkového počtu předaných 960 dotazníků, což je 52 \%, a dle jednotlivých kategorií dotazníků návratnost byla následující:

- Vyhodnocení průběhu př́pravy a provedení integračního procesu z personálně-sociálního pohledu, z 26 dotazníků, návratnost byla 26, tj. $100 \%$

- Obavy a očekávání vyplývající ze změn vyvolaných F\&A, z 870 dotazníků, návratnost byla $417, \mathrm{tj} .48 \%$

- $\quad$ Motivace pro akvizice z 33 dotazníků, návratnost byla 33, tj. 100\%;

- Klíčové faktory úspěšnosti F\&A, z 57dotazníků, návratnost byla 57, tj. 100\%

- Návratnost dle jednotlivých pracovních skupin, které byly dotazníky osloveny, je následující:

- z 450 zaměstnanců cílových společností dotazník vrátilo 190 zaměstnanců a z 220 zaměstnanců z 12 podniků, akvizitérů, dotazník vrátilo 90 zaměstnanců

- ze 115 vedoucích a mistrů (předáků) z 19 cílových českých společností dotazník vrátilo 75 vedoucích a mistrů (předáků)

- ze 45 vedoucích a mistrů (předáků) z 12 podniků, akvizitérů dotazník vrátilo 31 vedoucích a mistrů (předáků)

- $\quad$ z 25 specialistů z 19 cílových společností dotazník vrátilo 19 specialistů

- $\quad$ z 15 specialistů z 12 podniků, akvizitérů dotazník vrátilo 12 specialistů

- $\quad$ z 26 personalistů z 26 společností celkem se podílejících na všech transakcích dotazník vrátilo 26 personalistů

- z 33 top manažerů z 39 společností, které se podílely na všech transakcích, dotazník vrátilo 33 manažerů

\subsection{Motivace pro akvizice}

Šetření ukazuje, že nejdůležitějšími motivy, které přiměly akvizitory k rozhodnutí o provedení fúzí či akvizicí, je soulad s firemní strategií, zvýšení tržního podílu, dosažení synergických efektů a nové trhy. Naopak nejméně důležitým motivem jsou investiční prŕíležitosti před daňovými výhodami. 
Jak je možno vidět na obrázku č. 1 z celkového počtu 32 respondentů $87,9 \%$ ohodnotilo soulad s firemní strategií, 84,8\% respondentů ohodnotilo zvýšení tržního podílu, 81,8\% ohodnotilo nové trhy a $72,7 \%$ ohodnotilo dosažení synergie jako klíčové motivační faktory vedoucí k uzavření akvizičních transakcí. Nejméně respondentů, tj. pouze $3 \%$, ohodnotilo daňový motiv (viz obrázek č. 1) jako hlavní motivační faktor vedoucí k uzavření akviziční transakce.

\subsection{Výsledky šetř̌ení obav a očekávání jako důsledku změn plynoucích ze slučovací- ho procesu}

Personální a sociální důsledky akvizičních transakcí a procesů ve zkoumaných společnostech byly zjišt’ovány výzkumným šetřením dotazníkovou formou. Výzkumné šetření bylo provedeno ve dvou skupinách respondentů a to:

- Ve skupině specialistů, mistrů a vedoucích provozních pracovníků o celkovém počtu 137 respondentů;

- Ve skupině dělníků, o celkovém počtu 280 respondentů.

Obrázek 1 Motivy akvizic s největším a nejmenším vlivem na rozhodování respondentů

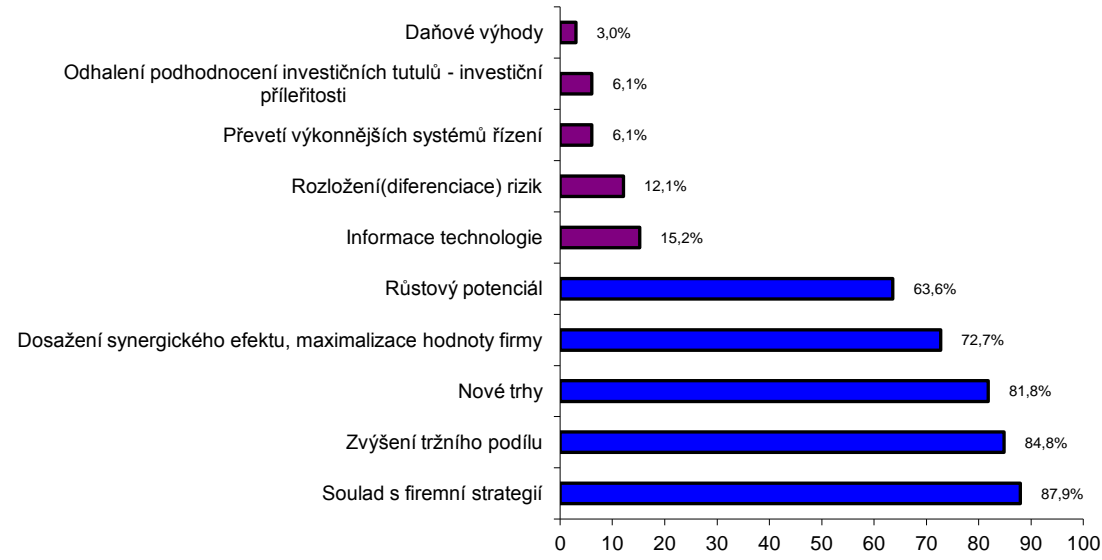

Zdroj:vlastní konstrukce

Cílem bylo zjistit, zda v průběhu přípravy transakce a následně integračního procesu vznikají obavy a strach $z$ očekávaných změn, jak rovněž šlo o stanovení příčin obav a strachu u obou skupin zaměstnanců. Současně šetření mělo za cíl stanovit, jaká jsou očekávání u obou skupin zaměstnanců, co očekávají od nových vlastníků, v nových podmínkách, po provedené integraci. Smyslem tohoto šetření je následná možnost reakce ze strany akvizitorů na tyto podněty a to vypracováním souborů opatření, které zjištěné druhy obav a strachu budou minimalizovat. Cílem je získat většinu zaměstnanců pro realizaci změn.

Získané údaje z tohoto šetření určují směr, kterým se akvizitoři a managementy mají ubírat, aby byly tyto obavy minimalizovány a tím bylo vytvořeno pozitivní klima spolupráce při realizaci stanovených úkolů transakce.

Dle průzkumu mezi zaměstnanci (řadoví pracovníci, dělníci) největší obavy, frustraci a strach vyvolává: obava ze ztráty zaměstnání, snížení odměny a př́ijmu, a tím také zhoršení životní situace. Nutnost změny pracovního zařazení, chybějící informovanost a zhoršení mezilidských vztahů jsou pak dalšími prvky, které vyvolávají v zaměstnancích strach a frustraci z připravované transakce. 
Průzkum mezi respondenty ve skupině vedoucích, mistrů a vedoucích provozních pracovníků ukazuje, že rozhodující vliv na rostoucí obavy a frustraci vyplývající z připravovaného slučovacího procesu mají: omezení oblasti vlivu moci a samostatnosti, nutnost změny zaměstnanecké kvalifikace, nevyhovění novým požadavkům, zhoršení mezilidských vztahů, chybějící informovanost, nutnost změny místa práce a bydliště z titulu ztráty místa a pozice.

Z průzkumu rovněž vyplývá, že nejčastěji vyjmenovaným př́nosem plynoucím z plánovaného slučovacího procesu jsou nové výzvy a zavádění nových technologií, větší možnosti profesního vývoje a realizace kariéry, možnost práce na nových strojích a zařizeních, zvýšená odměna a šance na rychlejší povýšení.

V př́padě, že akvizitor vůbec neřeší vznik negativních nálad u zaměstnanců a managementu, zvláště pak na začátku transakce, potom riziko neúspěchu akvizice či fúze je velmi vysoké. Tuto skutečnost výzkumné šetření potvrzuje. Současně toto šetření zjistilo, že ve většině zkoumaných transakcí řízení lidských zdrojů a usměrňování nálad zaměstnanců bylo nastartováno až $\mathrm{v}$ průběhu integrační fáze. $\mathrm{V}$ rámci řízení těchto procesů byly použity především informačně podpůrné kampaně, jejichž cílem bylo vysvětlit konkrétní plány a kroky nového vlastníka, a samozřejmě především stanoviska a záměry směrem k dalšímu rozvoji zaměstnanosti v podniku. K vysvětlování tohoto problému byly použity všechny dostupné komunikační kanály a prostředky (intranet, podnikové časopisy, „proximity meetings“ atd.).

\subsection{Výsledky výzkumného šetření faktorů ovlivňujících úspěšnost fúzí a akvizic}

Výzkumné šetření provedené dotazníkovou formou mezi 57 manažery určilo rozhodující faktory, které mohou významným způsobem ovlivnit výsledky slučovacího procesu.

Ankety se účastnilo 57 manažerů z různých společností a z různých odvětví (viz úvodní část odstavce 3 tohoto článku).

Data potřebná pro strukturalizaci a analýzu faktorů ovlivňující efektivnost F\&A byly získané dotazníkovým šetřením mezi 57 manažery ze společností uvedených v předchozích odstavcích tohoto článku.

Ze získaných dat byly vypočtené průměrné hodnoty jednotlivých faktorů a dle výsledků bylo sestavené pořadí významnosti od velmi důležitých po méně důležité. Takto je sestavený obrázek č. 2 , z tohoto obrázku je patrné, že prvních dvanáct faktorů je hodnoceno průměrnou známkou 1,1 až 1,6 , což znamená hodnocení jako velmi důležitý faktor úspěšnosti fúze či akvizice. Je potřeba zdůraznit, že ani poslední dvacátý faktor úspěšnosti není hodnocen známkou bezvýznamnosti. Ekonomická situace v zemi je ohodnocena průměrným hodnocením 3,2 což je označení méně důležitý faktor nikoliv však bezvýznamný. Na základě těchto výsledků byl sestaven seznam prvních 11 faktorů ovlivňujících efektivnost fúzí či akvizic.

1. Due diligence

2. Lidský faktor a řízení změn

3. Silné vedení v pointegrační fázi

4. Stanovení synergických efektů

5. Komunikace

6. Vedoucí týmu akceptovaný všemi stakeholders

7. Motivy, důvody fúze či akvizice

8. Aktivní řízení kulturních rozdílů

9. Fúze či akvizice je součástí strategie společnosti 
10. Eliminace jevu „vítěz a poražený“

11. Předakviziční plánování

Statistický výpočet intervalu spolehlivosti pro parametr alternativního rozdělení (faktory úspěšnosti $\mathrm{F} \& \mathrm{~A}$ ) prověřoval, zda alespoň $80 \%$ řídících pracovníků hodnotí faktory úspěšnosti uvedené v obrázku č. 2 jako velmi důležité (1) nebo důležité (2). Tento výrok byl ověřen na základě vypočítaných absolutních a relativních četností s využitím konstrukce $95 \%$ intervalu spolehlivosti $(95 \% \mathrm{CI})$ pro populační pravděpodobnost. Intervaly spolehlivosti byly spočítány jako meze spolehlivosti pro parametr alternativního rozdělení Likeš, J. a Laga, J, (1978). ${ }^{14}$

U prvních 11 faktorů intervaly spolehlivosti obsahovaly pouze hodnoty vyšší než 80\%, proto bylo možné u těchto faktorů stanovený předpoklad přijmout. Pouze u faktoru Silný integrační tým obsahoval interval spolehlivosti i hodnoty nižší než $80 \%$, předpoklad tedy nebyl přijat.

Obrázek 2 Klíčové faktory úspěšnosti seřazené podle významnosti

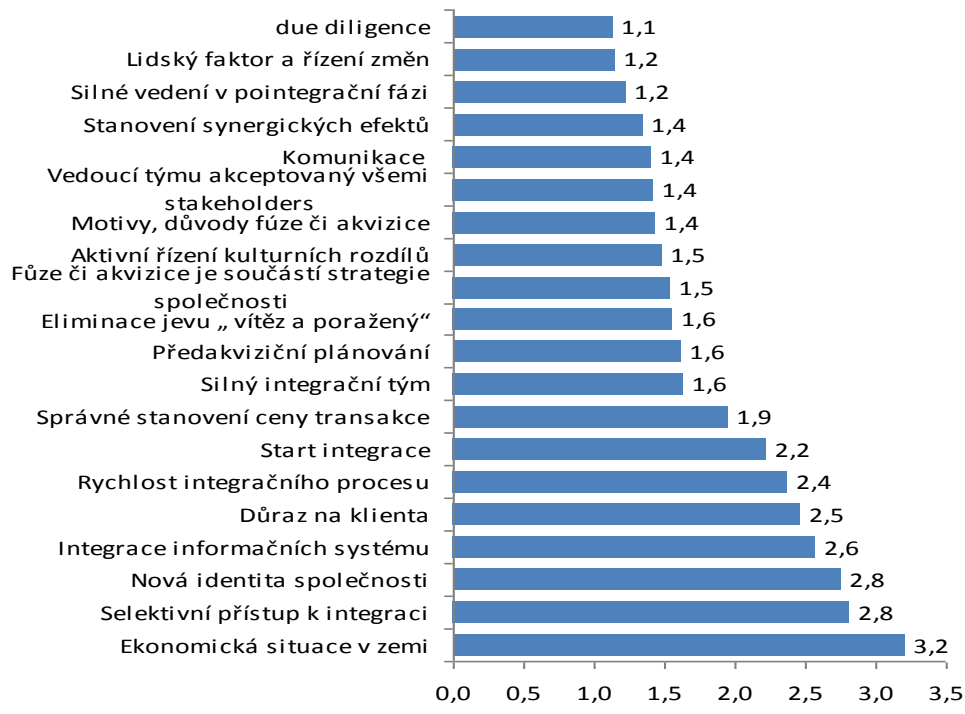

1 -velmi důležitý faktor

2 - důležitý faktor

3- méně důležitý faktor

4 - bezvýznamný faktor

5 - nevím

Zdroj: vlastní konstrukce

\subsection{Hodnocení úspěšnosti akviziční transakce pomocí ukazatele EVA (Economic Va- lue Added)}

Úspěšnost jednotlivých akvizic je hodnocena na základě porovnání úrovně tvorby ekonomické přidané hodnoty, neboli ekonomickým ziskem, v období předakvizičním s obdobím postakvizičním. Délka vyhodnocovaného období byla stanovena na období 3 let před a 3 roky po provedené akvizici. Tento časový úsek byl zvolen v souladu s názorem různých autorů, např́k lad Synek M. (2007), ${ }^{15}$ v jeho knize Manažerská ekonomika, Frąckowiak W. (2009) ${ }^{16}$ v knize Fuzje i przejęcia. Toto tříleté před a poakviziční období je rovněž aplikováno

\footnotetext{
${ }^{14}$ LIKEŠ, J., LAGA, J., Základni statistické tabulky. Praha : SNTL, 1978. s. 488. bez ISBN.

${ }^{15}$ SYNEK, M. a kol., Manažerská ekonomika. 4. aktualiz. vyd. Grada Publishing, a.s. 2007. 464 s. ISBN 978-80-247-1992-4. s. 378.

${ }^{16}$ FRĄCKOWIAK, W., Fuzje i Przejęcia . Warszawa : Polske Wydawnictvo Ekonomiczne, 2009. s. 492. ISBN 978-83-2081786-7. s. 465 .
} 
v různých výzkumných pracích, jako např́klad „The postmerger financial performance of hotel companies“ Li-Tzang(Jane) Hsu, SooCheong (Shawn) Jang (2007) ${ }^{17}$, nebo „The longterm operating performance of European mergers and acquisitions“ Martynova, Oosting. Renneboog (2006). ${ }^{18}$ Akcionáři očekávají pozitivní efekty v co nejkratším termínu, nechtějí čekat na nejistý výsledek léta, očekává se úspěch a zvýšení hodnoty v co nejkratším termínu.

V oblasti akademických prací a výzkumů, novou metodu měření výkonnosti podniku použil ve své výzkumné práci profesor z Cary Business School, Johns Hopkins, University v Baltimore, USA, Ken C. Yook a název jeho práce je: „The measurement of PostAcquisition Performance Using EVA“ (Měření postakviziční výkonnosti, úspěšnosti pomocí EVA) a zveřejněna byla v Quarterly Journal of Business and Economics Studies 43 (3 a 4) str. 67 - 83 v roce $2004 .{ }^{19}$ Důvodem použití metody EVA v jeho práci byly výhrady k běžným ukazatelům finanční analýzy hodnotícím účetní výsledky ziskovosti, které nezahrnují oblast nákladů vlastního kapitálu, jak uvádí tento autor v odstavci „A New Performance Measure“ své výzkumné práce.

Koncepce EVA byla zpracována a patentována společností Stern, Stewart\&Co., v roce 1999, jako nástroj k řízení a oceňování podniků. Základní vzorec pro výpočet ukazatele EVA:

$$
\mathbf{E V A}=\mathbf{N O P A T}-\mathbf{W A C C} * \mathbf{C} \quad(\text { vzorec } 1)^{20}
$$

Zde NOPAT $=$ zisk z provozní činnosti podniku po zdanění (Net Operating Profit After Taxes), $\mathbf{C}=$ kapitál vázaný v aktivech, která slouží provozní činnosti podniku (Capital), WACC = průměrné vážené náklady na kapitál (Weighted Average Cost of Capital).

EVA představuje rozdíl mezi provozním ziskem po zdanění a náklady na využívaný kapitál (cizí i vlastní). Kladné hodnoty EVA dosahujeme, když jsou uhrazeny nejen běžné náklady, ale i náklady kapitálu, včetně nákladů na vlastní kapitál. Základ tohoto př́stupu je maximalizace zisku. $^{21}$

Hlavním nástrojem analýzy výkonnosti ve vybraných podnicích se stal soubor softwarové aplikace MS Excel - SATE, který byl navržen a sestaven Ing. Rostislavem Kolaříkem, Ph.D. a jehož souhlas k použití tohoto softwaru byl poskytnut pro účely mé disertační práce.

Z výsledků zmíněných propočtů byla sestavena souhrnná tabulka, ${ }^{22}$ ze které vyplývá skutečnost, že z celkového počtu 19 transakcí bylo úspěšných pouze 5 , neúspěšných 12 a dvě transakce byly se stejnými výsledky před i po transakci.

\footnotetext{
${ }^{17}$ HSU, L., JANG, S., The Postmerger Financial Performance of Hotel Companies, Dostupné na www:<http://ebookbrowse.com/hsu-yang-2007-the-postmerger-financial-performance-of-hotel-companies-pdf-d61005413>. ${ }^{18}$ MARTYNOVA, M.,OOSTING, S., RENNEBOOG, L., The long-term operating performance of European mergers and acquisitions, Finance working paper $\mathrm{N}^{\circ} .137 / 2006$, November. 2006, Dostupné na www:< http://www.marketobservation.ch/blogs/media/blogs/c_f/20072602-EuropMA.pdf >.

${ }^{19}$ YOOK, K. C., The measurement of post-acquisition performance usány EVA. Quarterly Journal of Business end Economics, University of Nebraska-Lincoln, June 22.,2004,svazek 43, vyyd. 3-4 : s. 67., Dostupný také z WWW: <file:///C:/Documents\%20and\%20Settings/J002748/Local\%20Settings/Temporary\%20Internet\%20Files/OLK5D4/The\%20m easurement $\% 20 \mathrm{of} \% 20$ post-acquisition\%20performance\%20using\%20EVA\%20(economic\%20value\%20added).htm>

${ }^{20}$ KISLINGEROVÁ, E., Oceňování podniku. 2. přeprac. vyd. Praha : C. H. Beck, 2001, 367 s. ISBN 80-7179-529-1. s. 88.

${ }^{21}$ KISLINGEROVÁ, E., Oceňováni podniku. 2. přeprac. vyd. Praha : C. H. Beck, 2001, 367 s. ISBN 80-7179-529-1. s. 88.

${ }^{22}$ KONKOLSKI, S., Strukturalizace a analýza faktorů ovlivñujicích efektivnost fúzí a akvizic. 2011. $192 \mathrm{~s}$ bez ISBN. s $113-$ 115
} 
Uvedené výzkumné šetření přineslo poměrně překvapivé výsledky. Pouze jedna třetina zkoumaných transakcí přinesla větší hodnotu EVA po provedené integraci a více než polovina transakcí nepřinesla zvýšení hodnoty EVA, naopak došlo k poklesu hodnoty, a tudíž 63,2\% transakcí je hodnoceno jako neúspěšné.

\section{Důvody neúspěchů integračních procesů $\mathrm{F} \& A$}

Důvody neúspěchů integračních procesů ve třinácti zkoumaných společnostech byly zjišt'ovány pomoci rozhovorů mezi 25 manažery, kteří se prrímo podíleli na př́pravě a řízení integračních procesů ve všech 19 zkoumaných př́ípadech.

Z uvedeného vyhodnocení vyplývá, že ve společnostech kde hodnota EVA a taktéž hodnota ukazatele EVA/vlastní kapitál klesla po provedeném integračním procesu, nebyly důsledně nebo vůbec řešeny následující oblasti:

1. V oblasti lidských zdrojů nebyly přizpůsobeny nástroje řízení podstatně změněným podmínkám v průběhu integrace. Nebyly zavedeny nové motivační systémy odměňování, systémy vzdělávání a školení. Působení na zaměstnance s cílem identifikace se záměrem organizace nebylo v žádné společnosti důsledně uplatněno, zaměstnanci nebyli informováni, jak budou zabezpečeny jejich sociální jistoty $\mathrm{v}$ případě organizačních změn, které doprovázely každý integrační proces, tak nebyly stanoveny metody a způsoby řešení sociálních dopadů, kromě těch, které prosadily odborové organizace ve svých kolektivních smlouvách. Nebyl připraven žádný plán akcí, jejichž cílem by bylo minimalizovat odpor středního článku řízení proti změnám, možnost seznámení se s organizací akvizitora byla minimální a většinou pouze prostřednictvím běžně dostupných zdrojů (internet, média, známí atd.).

2. Téměř ve všech podnicích lze hovořit o špatné komunikaci. Většinou pouze ve fázi předintegrační byli zaměstnanci seznámeni se záměrem $\mathrm{F} \& \mathrm{~A}$ a o dalším průběhu byli informováni pouze vrcholoví pracovníci a poradenské společnosti.

3. Častým jevem bylo špatné, v některých př́ípadech (VPFM, a.s.) žádné due diligence. Většinou provedené due diligence se týkaly pouze oblasti financí a účetnictví. Úplně vynechanou oblastí je ekologie a staré ekologické zátěže.

4. Plán integračního procesu byl vypracován pouze v 5 případech prováděných akvizičních procesech. Tyto plány integračního procesu neobsahovaly dostatečný objem finančních prostředků nutných k realizaci integračního procesu. Často tyto prostředky nebyly vyčleněny vůbec.

5. Vedoucí pracovníci nebyli dostatečně teoreticky připraveni, a bez zkušeností, tyto integrační procesy řídit.

\section{Statistické ověření vlivu některých faktorů úspěšnosti F\&A na změnu výkonnosti slučovaných společností}

Na základě zjištění z předchozího šetření jsou zkoumané podniky rozděleny do dvou skupin. První skupina zahrnuje ty podniky, které aplikovaly př́slušný faktor ovlivňující úspěch akviziční transakce a druhá skupina zahrnuje ty podniky, které tento faktor neaplikovaly vůbec. Takto bylo vytvořeno sedm souborů podniků s rozdělením na ty, které aplikovaly př́slušný faktor a ty které jej neaplikovaly. Pro porovnání těchto podniků, rozdělených dle sedmi kritérií (Due diligence, formulace strategie společnosti a motivy F\&A, manažerský tým - silné vedení v pointegrační fázi a vedoucí týmu akceptovaný všemi stakeholders, synergické efekty, plán integrace, sociální a personální plány - aktivní ř́zení kulturních rozdílů včetně elimi- 
nace jevů „vítěz a poražený“, komunikace) před a po transakci jsou použity čtyři ukazatelé (EVA/aktiva, EVA/tržby, EBITDA/aktiva, EBITDA/tržby). Hodnocené období je znovu 3 roky před a 3 roky po akvizici.

Toto porovnání bylo provedeno dvouvýběrovými neparametrickými Mann-Whitney U-testy. Ke statistickému zpracování byl použit statistický software SPSS verze 15 a program Microsoft Office 2007 . Všechny statistické testy byly provedeny na hladině signifikance $0,05{ }^{23}$

Závěrem je možné konstatovat, že byly nalezeny statisticky významné rozdíly v růstu výkonnosti u podniků, které aplikovaly faktory úspěšnosti při realizaci akvizičního procesu ve srovnání s podniky, které tyto faktory úspěšnosti neaplikovaly. Jedná se o faktory správné komunikace, sociální a personální plány - aktivní řízení kulturních rozdílů včetně eliminace jevů „vítěz a poražený“, plány integrace, jmenovaní vyškoleného managementu - silné vedení v pointegrační fázi a vedoucí týmu akceptovaný všemi stakeholders. U ostatních faktorů (due diligence, stanovení strategie a motivů F\&A, stanovení synergií) nebyly zjištěny žádné statisticky významné rozdíly. Doporučuji v blízké budoucnosti provést podobné výzkumné šetření a analýzu jednotlivých faktorů ovlivňující úspěšnost, efektivnost, výkonnost F\&A na podstatně větším, statisticky významnějším vzorku podniků. Vzhledem k tomu, že MPO ČR již od roku 2006 sestavuje finanční analýzu podnikové sféry, bylo by možné měření změn výkonnosti podniku po převzetí, srovnávat s výkonností, upravenou o oborové trendy.

\section{Návrh souborů postupů ř́zení projektů fúzí či akvizic (F\&A), které zvýší prav- děpodobnost úspěšnosti a efektivnosti těchto projektů}

Již samotné zjištění a stanovení okruhu klíčových faktorů úspěšnosti fúzí či akvizic vytváří rámec a směr, kterým by se potenciální akvizitor měl ubírat v prrípadě rozhodnutí realizovat akvizici (fúzi).

Proto návrh postupů zvyšujících pravděpodobnost úspěchu fúze či akvizice je se zjištěnými klíčovými faktory úspěchů svázán a z tohoto stanoveného rámce nevybočuje a zahrnuje tyto oblasti:

1. Sestavení a aplikace plánu integračního procesu

2. Jmenování managementu pro realizaci integračního procesu

3. Návrh opatření v oblasti lidských zdrojů

4. Důsledné provedení due diligence ${ }^{24}$

\section{Závěr}

Tento článek prezentuje poznatky získané z řešení problematiky mé disertační práce „Strukturalizace a analýza faktorů ovlivňujících efektivnost fúzí a akvizic." Hlavním cílem této práce bylo stanovit klíčové faktory ovlivňující efektivnost fúzí a akvizic a stanovit soubor postupů řízení projektů fúzí a akvizic, které zvýší pravděpodobnost úspěšnosti a efektivnosti těchto projektů.

\footnotetext{
${ }^{23}$ KONKOLSKI, S., Strukturalizace a analýza faktorů ovlivňujicich efektivnost fúzí a akvizic. 2011. 192 s bez ISBN. s 120123

${ }^{24}$ KONKOLSKI, S., Strukturalizace a analýza faktorů ovlivňujicich efektivnost fúzí a akvizic. 2011. $192 \mathrm{~s}$ bez ISBN. s 125139
} 
V průběhu zpracování disertační práce a hlavně během zpracovávání výzkumných šetření a př́padových studií byly prakticky ověřovány poznatky získané kritickou literární rešerší a navržené soubory opatření ke zvýšení pravděpodobnosti úspěchu projektů fúzí či akvizic. Šetřením a provedenými rozbory na vybraném vzorku podniků a vzorku zaměstnanců a manažerů v 39 společnostech byla zmapována situace v oblasti fúzí či akvizic a bylo určeno jedenáct klíčových faktorů ovlivňujících efektivnost fúzí a akvizic. Byly rovněž zjištěny hlavní motivy, které přiměly majitele a manažery českých podniků k rozhodujícímu kroku a provedení akviziční transakce. Dále bylo zjištěno, že $26,3 \%$ zkoumaných českých podniků v rámci F\&A bylo úspěšných, a to měřeno hodnotou ukazatele EVA. V 63,2\% podniků došlo $\mathrm{k}$ poklesu hodnoty EVA po provedené transakci a v 10,5\% podniků nedošlo k žádné výrazné změně. $\mathrm{V}$ disertační práci jsou rovněž uvedeny příčiny a důvody neúspěchu akvizičního procesu (měřeno pomoci EVA), které byly zjištěny pomoci rozhovorů mezi 25 manažery, kteří se prrímo podíleli na prrípravě a řízení integračních procesů ve všech 19 zkoumaných prrípadech. Získané odpovědi byly vyhodnoceny a bylo možné konstatovat, že $63,2 \%$ neúspěšných transakcí bylo ovlivněných především:

$>$ V oblasti lidských zdrojů nebyly přizpůsobeny nástroje řízení podstatně změněným podmínkám v průběhu integrace. Nebyly zavedeny nové motivační systémy odměňování, systémy vzdělávání a školení. Působení na zaměstnance s cílem identifikace se záměrem organizace nebylo v žádné společnosti důsledně uplatněno, zaměstnanci nebyli informováni, jak budou zabezpečeny jejich sociální jistoty v případě organizačních změn, které doprovázely každý integrační proces, také nebyly stanoveny metody a způsoby řešení sociálních dopadů kromě těch, které prosadily odborové organizace ve svých kolektivních smlouvách. Nebyl připraven žádný plán akcí, jejichž cílem by bylo minimalizovat odpor středního článku řízení proti změnám, možnost seznámení se s organizací akvizitora byla minimální a většinou pouze prostřednictvím běžně dostupných zdrojů (internet, média, známí atd.).

> Téměř ve všech podnicích lze hovořit o špatné komunikaci. Většinou pouze ve fázi předintegrační byli zaměstnanci seznámeni se záměrem F\&A a o dalším průběhu byli informováni pouze vrcholoví pracovníci a poradenské společnosti.

$>$ Častým jevem bylo špatné, v některých př́ípadech (VPFM a.s.) žádné due diligence. Provedené due diligence se týkaly pouze oblasti financí a účetnictví. Úplně vynechanou oblastí je ekologie a staré ekologické zátěže.

> Plán integračního procesu byl vypracován pouze $\mathrm{v} 5$ př́padech prováděných akvizičních procesech. Tyto plány integračního procesu neobsahovaly dostatečný objem finančních prostředků nutných $\mathrm{k}$ realizaci integračního procesu. Často tyto prostředky nebyly vyčleněny vůbec.

$>$ Vedoucí pracovníci nebyli dostatečně teoreticky připraveni a bez zkušeností tyto integrační procesy řídili.

Jsem přesvědčen, že v rámci disertační práce „Strukturalizace a analýza faktorů ovlivňující efektivnost fúzí a akvizic“ se podařilo přehledně stanovit hlavní problémy, které jsou s integračními procesy spojeny. Rovněž si myslím, že se podařilo stanovit hlavní směry, kterými se akvizitoři musí vydat během postintegračního období $F \& A$, aby pravděpodobnost úspěchu F\&A byla maximální. 


\section{Literatura}

[1] ARMSTRONG, M., Řizení lidských zdrojů: Nejnovější trendy a postupy. 10. vyd. Praha: Grada Publishing, 2007. s. 800. Zaměstnanecké výhody, penze a př́platky, ISBN 9788024714073. s.95-599.

[2] BREALEY R.A.,MYERS S.C., Teorie a praxe firemnich financi Praha:Victoria Publishing,a.s.,1992. s. 971. ISBN 80-85605-24-4.

[3] BREJCHA, M., Jak chápat profesionalitu manažera. Mariánské Lázně, 2006. Příspěvek konference General Management, Mariánské Lázně 2006. Sdružení EVIDA Plzeň, profesní vzdělávání.

[4] BROWNE, M. J., \& GATE, G.H., Due Diligence, Mergers and Acquisitions,., s. 60; The Acquisitions Manual, S.N. Levine (ed.), New York Institute of France, New York s. 1989. s. 109-146.

[5] CARTURIGHT, S., COOPER, C.L., Kiedy firmy tacza sie lub sa przejmowane. Strategie, konflikty, rozwiazania, Petit, Warszawa 2001, s.53.

[6] COPELAND,T., KOLLER,T., MURRIN,J.,Stanoveni hodnoty firem 1.vyd.Praha,Victoria Publishing,a.s. 1991. ISBN 80-85605-41-4.

[7] DAMODARAN A., Valuing Acquisitions, www.nyn.edu(,adamodar")

[8] DASZKIEWICZ, N., Internacjonalizacja matych i średnich przedsiębiorstw we wspótczesnej gospodarce. Gdańsk : VM Group, 2004. s.196. ISBN 83-921075-0-0.

[9] DĚDIČ, J., ŠTENGLOVÁ, I., ČECH, P., KŘÍŽ, R., Akciové společnosti. 6. přepracované vyd. Praha: C. H. BECK, 2007.s. 944. ISBN:7179-587-2. s. 23.

[10] DLUHOŠOVÁ, D., a kol., Finanční ř́zení a rozhodování podniku., Analýza, investování, Oceňování, Riziko, Flexibilita. 3. rozšířené vyd. Praha: EKOPRESS, 2010. s. 223. ISBN:978-80-86929-68-2.

[11] DRLÍKOVÁ, Z., Vývoj fúzí a akvizic v České republice. Praha, 2007. 105 s. Diplomová práce. Univerzita Karlova v Praze, Fakulta sociálních věd, Institud ekonomických studií.

[12] DRUCKER, P.F., The Five Rules for Successful Acquisition, „Wall street Journal“ 1981 october 15.

[13] DRUCKER, P.F., The Daily Drucker: 366 Days of Insight and Motivation for Getting the Right Things Done Publisher: Collins Business, 2004-10-26, ISBN: 0060742445.

[14] DVOŘÁK, T., Společnost s ručením omezeným. Praha: ASPI, 2008. 325 s, ISBN 97880-7357-344-7.

[15] DVOŘÁK, T., Akciová společnost a Evropská společnost. Praha: ASPI, 2005. 614 s. ISBN: 978-80-7357-430-7.

[16] DYTRT, Z. a kol., Etika v podnikatelském prostředí, Grada Publishing, a. s. , Praha, 2006, ISBN 80-247-1589-9.

[17] DONNELLY, J., H., GIBSON, J. L., IVANCEVICH, J. M., Management. 1. vyd. Praha: Grada, 1997. 1 s. ISBN 80-7169-422-3.

[18] ELIÁS̆, K., BARTOŠÍKOVÁ, M., POKORNÁ, J. a kol., Kurz obchodního práva. Právnické osoby jako podnikatelé. 5. vydání. Praha: C. H. BECK, 2005. 25 s. ISBN 807179-658-1.

[19] FOLTYN, W., Analiza Due Diligence w itegraciji przedsiębiorstw: Warszawa: Poltext, 2005. s.164. ISBN 83-88840-71-1.

[20] FRAC_CKOWIAK, W., Fuzje i przejęcia : Redakcja naukova. Warszawa: Ekonomiczne S.A., 2009. s.512. ISBN 978-83-208-1786-7.

[21] GALPIN T., J.,HERNDON M., The Complete Guide to Mergers and Acquisitions: Process Tools to Support M\&A Integration at Every Level, 2nd Edition. 
[22] Harvard Bussiess Review. Harvard Business School Press. Fuzje i przejęcia. Gliwice.: Helion, 2006.211 s. ISBN 83-7361-908-9.

[23] HAZEL, J., Fuzje i przejęcia: Narzędzie podejmowania decyzji strategicznych.1. wyd. Warszawa: K. E. Liber 2000. 196 s. ISBN 83-88170-14-7.

[24] HERDAN, A., Fuzje i przejęcia. Wybrane aspekty integraci. Pod redakcją Agnieszki Herdan.1.vyd. Kraków: Universytet Jagiellońskiego. 2008. 167 s. ISBN 978-83-2332476-8.

[25] HOOKE, J.C., Fuzje i przejęcia. Jak skutecznie prueprowadzać transakce. Wydawnictwo Liber, Warszawa 2001. $19 \mathrm{~s}$.

[26] HOOKE, J. C., Fuzje i przejęcia : Jak skutecznie przeprowadzić transakcję. Warszawa: K.E.Liber, 2002. 294 s. ISBN 83-909502-7-8.

[27] JENSEN, M. C., Eclipse Of The Public Corporation.Harvard Business Review září/ř́ijen 1989., Dostupný také z www:

<http://www.people.hbs.edu/mjensen/pub2.html>.

[28] JENSEN, M. C., The Sfficiency Of Takeovers. The Corporatee Boarde,záŕí/ř́ijen 1985., Dostupný také z www: <http://www.people.hbs.edu/mjensen/pub2.html>.

[29] JENSEN, M. C., The Takeover Controversy:Analysis And Evidence.Midland Corporate Finance Journal,2/1986., Dostupný také z www:

<http://www.people.hbs.edu/mjensen/pub2.html>.

[30] JENSEN, M.C., Value Maximization, Stakeholder Theory, And The Corporate Objektive Function.Harvadr Business Schoul Working \#00-058 2/2001., Dostupný také z www: <http://www.people.hbs.edu/mjensen/pub2.html>.

[31] JENSEN, M. C., MECKLING,W.H., Theory Of The Firm : Managerial Behavior,Agency Costs And Ownership Structure.Journal Of Financial Economics, 4/1976., Dostupný také z www: <http://www.people.hbs.edu/mjensen/pub2.html>.

[32] JENSEN, M. C., Is Leverage An Invitation To Bancruptcy?The Wall Street Journal z 1/2/1989., Dostupný také z www: <http://www.people.hbs.edu/mjensen/pub2.html>.

[33] KAY,I.T., SHELTON, M., The People Problem In Mergers.The McKinsey Quarterly, 4/2000.

[34] KAPLAN, R. S., NORTON, D. P., Balanced Scorecard: Strategický systém měreni výkonnosti podniku. 5. vyd. Praha: Management Press, 2007. 267 s. ISBN 978-807261-177-5.

[35] KAŹMIERSKA, JÓŹWIAK, B., Kluczove czynninki powodzenia fuzji a przejęć przedsiębiorstw. „Przeglad Organizacji“2002,nr.9, s. 18.

[36] KEŘKOVSKÝ, M., VYKYPĚL, O., Strategické ř́zení : Teorie pro praxi. 2nd edition. Praha: C.H.Beck, 2006, s. 206, ISBN 80-7179-453-8.

[37] KISLINGEROVÁ, E., Oceňování podniku. 2. přeprac. vyd. Praha : C. H. Beck, 2001. 144 s. ISBN 80-7179-529-1.

[38] KOHOUT, P., Investiční strategie pro třetí tisíciletí. 2. vyd. Praha: GRADA Publishing, spol. s.r.o. 2001. 203 s. ISBN 80-247-0074-3.

[39] KELLY. J., COOK C., SPITZER, D., Unlocking shareholder value: The keys to success: Merges\&Acquisitionc:Global Rescarch Report KPMG,1999.

[40] KERLINGER, F. N., Základy výzkumu chování: pedagogický a psychologický výzkum. Fred N. Kerlinger. Vyd. 1. Praha: Academia, 1972. 705 s. il.

[41] KONKOLSKI, S., Strukturalizace a analýza faktorů ovlivňujících efektivnost fúzí a akvizic. 2011. $192 \mathrm{~s}$ bez ISBN. s 125-139

[42] LOUŠA, F., Účetnictví podnikateli 2006 : výklad je zpracován k právnímu stavu ke dni 1.1.2006. Praha: ASPI, 2006. 758 s. ISBN 80-735-7155-2.

[43] MACHAŁA, R., Przejęcia i fuzje: Wpływ na wartość firm. 1. . wyd. Wrocław : Unimex-Oficyna wydawnicza, 2007. 312 s. ISBN 83-60235-30-0. 
[44] MACHAŁA, R., Fuzje i przejęcia wptyw na wartość firm. 1.vyd.Wrocław: Unimex, 2007. 312 s.ISBN 978-83-60235-20-0.

[45] SYNEK, M., A KOL., Manažerská ekonomika. 4. aktualizované rozšířené vydání, Grada Praha 2007, ISBN:80-247-1992-4.

[46] MALLYA, T., Základy strategického řizení a rozhodování. Praha: Grada Publishing, a.s., 2007. s. 246. ISBN 978-80-247-1911-5.

[47] MALÝ, M., Nepratelske prevzeti metody a strategie obrany. IHNED.CZ : Moderní řízení. 8.9.2006., 2006, 9, s. 1. Dostupný také z WWW: <modernirizeni.inhned.cz>.

[48] MAŘÍK, M. Koupě podniku jako součást podnikové strategie. Praha: VŠE. 1997. 176 s. ISBN 80-7079-558-1.

[49] MǍ̌ÍK, M. Určování hodnoty firem. 1. vyd.Praha: Ekopress, 1998. 206 s. ISBN 8086119-09-2.

[50] MAŘÍK, M., a kolektiv. Metody oceňování podniku: Proces ocenění základnímetody a postupy. 1. vyd. Praha 4 : Ekopress, 2003. 402 s. ISBN 80-86119-57-2.

[51] MOLNAR, Z., Úvod do základi̊ védecké práce. Sylabus pro potřeby semináre doktorandi̊. [online]. Praha: Vysoka škola ekonomická, Katedra informačních technologií, 2008. [citováno 2011-01-17]. Dostupné na:

http://kit.vse.cz/kit/WCMS_KIT.nsf/pages/ZakladyVedeckePrace.html>. 23 s.

[52] NEUMAIEROVÁ, I., NEUMAIER, I., Výkonnost a tržní hodnota firmy. 1 vyd. Praha 2002. Grada Publishing a.. 215s. ISBN 80-247-0125-1.

[53] PANKAU, E., et al. UNIFIKACJA GOSPODAREK EUROPEJSKICH SZANSE I ZAGROŻENIA : Wyzwania dla Polityki konkurencji w gospodarce globalnej. 1. wyd. Warszawa : [s.n.], 2004. 477 s. ISBN 83-89069-66-0..

[54] PAUTLER, P., A.,The Efects of Mergers and Post-Merger Integration: A Review of Business Consulting Literature January 21, 2003 version, s.6.

[55] PAYNE, A., Approaching Acquisitions Strategically. „Journal of General Management“ $1987 \mathrm{nr}$.

[56] PERKINS, S. J., Internationalization: The People Dimension, Kogan Page, London 1997.

[57] POLÁČEK, B., ATTL, J., Posudek znalce a podnik. Praha: C. H. BECK, 2006. s. 184, ISBN: 80-7179-503-8. s.23.

[58] PORTER, M. E., Konkurenční strategie. Přel. K. Kvapil. Praha: Victoria Publishing, 1994. s.403. Přel. z Competitive Strategy. ISBN 80-85605-11-2.

[59] POCZTOWSKI, A., Fuzje $i$ przejęcia $w$ gospodarce,[w:] Zarządzanie zásobami ludzkimi w procesach fuzji i przejęć, red. A Pocztowski, Oficyna Ekonomiczna, Kraków 2004, s. 13.

[60] POCZTOWSKI, A., Zarzadzanie zasobami ludzkimi. Strategie, procesy, metoda, PWE, Warszawa 2003 s. 60.

[61] PERETZ, A., Od kartelu do koncernu. 1. wyd. Warszawa : Przemysł i handel, 1929. s. 9.

[62] PORTER, M. E., Konkurenční výhoda. Přel. V. Irgl. Praha: Victoria Publishing. 626 s.. Přel. z Competitive Advantage: ISBN 80-85605-12-0.

[63] RANKINE, D., HOWSON, P., Przejęcia strategie i procedury: Warszawa: Ekonomiczne S.A., 2008. s.223. ISBN 978-83-208-1771-3.

[64] RAPPAPORT, A., Wartość dla akcjonariusz. Přel. M. Nowak. Wig-Press Warszava 1999. 206 s. ISBN 83-87014-35-4.

[65] SEARBY, F. W. Control Postmerger Change. „Harvard Business Review“ 1969, September-October,s 6.

[66] SOLǍ̌, J., BARTOŇ, V., Rozbor výkonnosti firmy. VUT Brno. Studijní text, 2003. s. 173. ISBN 80-214-2515-6. 
[67] SUDARSANAM, P.S., Creating Value from Mergers and Acquisitions, The Challengers, Prentice Hall, 2003. s. 593. ISBN10:0-201-72150-3

[68] SUDARSANAM, P.S., The Essence of Mergers and Acquisitions, Prentice Hall, London, New York, 1995, s. 4-5.

[69] SYNEK, M. a kol., Manažerská ekonomika. 4. aktualiz. vyd. Grada Publishing, a.s. 2007. s. 464. ISBN 978-80-247-1992-4.

[70] SYNEK, M., Nauka o podniku. 1. vyd. Praha, Vysoká škola ekonomická, 1994, ISBN 80-7079- 892-0.

[71] SZABLEWSKI, A.,PNIEWSKI, K.,BARTOSZEWICZ, B., Value Based Management. koncepcje, narzędzia, przykłady. Deloitte, Warszawa, Poltext 2008. s.711. ISBN 97883-7561-002-4.

[72] ŠANTRŮČEK, J., Fúze a akvizice. 1.vyd.SYNEK M., Nauka o podniku 1. vyd. Vysoká škola ekonomická v Praze: Institut oceňování majetku, 2001. s.129. ISBN 80-245 0234-6.

[73] ŠTENGLOVÁ, I., PLÍVA, S., TOMSA, M. a kol., Obchodní zákoník. Komentář. 11. vydání. Praha: C. H. BECK, 2006. s.206. ISBN 80-7179-487-2.

[74] VEBER, J. a kol., Management. Základy-prosperita-globalizace. Praha: Management Press, 2002. ISBN 80-7261-029-5.

[75] VOMÁČKOVÁ, H., Účetnictví akvizicí, fúzí a jiných vlastnických transakcí. Praha:Polygon, 2006. ISBN 80-7273-127-0.

[76] VOMÁČKOVÁ, H., Účetnictví akvizicí,fúzí a jiných vlastnických transakcí. 2. vydání Praha: Polygon, 2004. s.500. ISBN 80-7273-108-4.

[77] WERNER, R., Podnikové hospodářství. 4. vydání. Praha: Západočeská univerzita, 2002. s.143. ISBN 80-7182-604-5.

[78] WEST, S., COUNT, L., Expatriate Family Atress., The Hideu cost., Dostupný také z www: www.vejovnal.com/may 97/expats.htm; Carturight, S. i Cooper, C.L.op.cit.,s. 90-97.

[79] YOOK, K. C., The measurement of post-acquisition performance usány EVA. Quarterly Journal of Business nad Economics, University of Nebraska-Lincoln, June 22.,2004,svazek 43, vyd. 3-4 : s. 67., Dostupný také z www:

<file://C:/Documents\%20and\%20Settings/J002748/Local\%20Settings/Temporary\%20I nternet\%20Files/OLK5D4/The\%20measurement\%20of\%20postacquisition\%20performance\%20using\%20EVA\%20(economic\%20value\%20added).htm>.

[80] ZAJĄC, Cz., Społeczne i organizacyjne problemy przejęć i fuzji przedsiębiorstw.. 2. wyd. Wrocław : Akademii Ekonomicznej we Wrocławiu, 2006. 215 s. ISBN 83-7011807-0.

\section{Internetové zdroje}

http://businessworld.cz/pruzkumy-a-analyzy/nejvic-fuzi-a-akvizic-v-evrope-bylo-vloni-ve-

financnich-sluzbach-2197

www.mestskymarketing.cz/delf.php

www.afi.cz/data/files/kpmg-global-m-a-predicator-cz-105.pdf

www.morganstanley.com Morgan stanley, 2006

www.business.center.cz

www.damodaran.com

www.fame.utb.cz

www.dlapiper.com 
www.imaa-institute.org/statistics-mergers-

acquisiti-

ons.html\#MergersAcquisitions_United Kingdom

www.kpmgcorporatefinance.com

www.tfsd.com

http://en.wikipedia.org/wiki/Merger

www.meregersat.com/website

www.pwc.com

www.hn.ihned.cz

www.vejovnal.com

www.awpagesociety.com

www.getechnologylending.com

www.ecgi.org/wp

\section{Classification JEL: G39}

\section{Ing. Stanislav Konkolski}

ArcelorMittal Tubular Products Karviná a.s.

Rudé armády 471

72323 Karviná - Hranice

stanislav.konkolski@ arcelormittal.com 